\title{
Public fear of COVID-19 vaccines in Iraqi Kurdistan region: a cross-sectional study
}

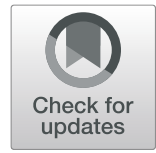

\author{
Arazoo Issa Tahir ${ }^{*}$ (D), Dilkhosh Shamal Ramadhan², Ari Ahmed Taha ${ }^{3}$, Rebar Yahya Abdullah², \\ Saad Kazim Karim ${ }^{4}$ (D) Azad Karim Ahmed ${ }^{5}$ and Shalaw Faris Ahmed ${ }^{6}$
}

\begin{abstract}
Background: Vaccines remain one of the most effective methods to control infectious diseases; however, COVID-19 vaccines are challenging and novel. Vaccine support is still substantial in general, although vaccination fear has increased dramatically in recent decades. This is the first study aimed to determine the fear of the COVID-19 vaccination and the role of factors and reasons associated with fear in the Iraqi Kurdistan region.

Results: A total of 1188 participants responded to the questionnaire about their fears of the COVID-19 vaccine. The majority of participants had a medium level of fear (56.7\%). Fear was significantly $(p<0.001)$ associated with major demographic characteristics, social media use (51.8\%), and losing family members, while other variables (previous seasonal influenza vaccine, previous infection, chronic medical diseases) show no relationship. Fear of side effects such as blood clotting was reported by the majority $(45.03 \%)$ and indicated positive relation $(p<0.016)$. On the other hand, a high proportion, 39.9\% and 34.01\%, were afraid of AstraZeneca and Pfizer ( $p<0.001)$, respectively; however, only about $4.63 \%$ had fear of Sinopharm.

Conclusions: The fear of COVID-19 vaccination was widespread in the Iraqi Kurdistan region. In this way, fear was related to significant variables. To reduce the fear of vaccines and increase public acceptance, authorities and the Ministry of Health should initiate a public awareness campaign. As a result, the public health crisis will significantly improve.
\end{abstract}

Keywords: Fear, COVID-19 vaccines, Kurdistan Region of Iraq

\section{Background}

The COVID-19 pandemic has already had a massive effect on communities around the world, with limits on travel and other preventive measures, including obligatory face coverings or quarantine being implemented to control the spreading of the virus $[1,2]$. Nevertheless, it is known that such preventive steps may not be adequate to stop COVID-19 from spreading. As a result, developing and deploying the vaccine is among the most effective health intervention methods for preventing COVID19 transmission [3-5]. Vaccination has been reported as one of the top notable public health achievements to

\footnotetext{
*Correspondence: arazoo.tahir@dpu.edu.krd; arezu.issa@gmail.com ${ }^{1}$ Bardarash Technical Institute, Nursing Department, Duhok Polytechnic University, Duhok Governorate, Duhok, Kurdistan Region, Iraq Full list of author information is available at the end of the article
}

have occurred during the twentieth century. It has resulted in the eradication of smallpox and control of poliomyelitis, measles, rubella, tetanus, diphtheria, and other infectious diseases [6]. The development of vaccines against COVID-19 has made rapid progress in the last year, and to date, three different vaccines showed good efficacy against COVID-19 [5, 7]. Positive results from clinical trials demonstrate that the COVID-19 vaccine is both safe and effective. The efficacy of a vaccine campaign, however, will be determined by population uptake rates. It is essential to begin planning and establishing successful vaccination strategies and marketing as soon as possible to ensure the highest possible uptake [8]. In the context of control of the COVID-19 pandemic, the willingness of the population in favor of vaccination may grow to hesitancy or fear from vaccination
Springer Open
(๑) The Author(s). 2021 Open Access This article is licensed under a Creative Commons Attribution 4.0 International License, which permits use, sharing, adaptation, distribution and reproduction in any medium or format, as long as you give appropriate credit to the original author(s) and the source, provide a link to the Creative Commons licence, and indicate if changes were made. The images or other third party material in this article are included in the article's Creative Commons licence, unless indicated otherwise in a credit line to the material. If material is not included in the article's Creative Commons licence and your intended use is not permitted by statutory regulation or exceeds the permitted use, you will need to obtain permission directly from the copyright holder. To view a copy of this licence, visit http://creativecommons.org/licenses/by/4.0/. 
[9]. In general, vaccine support is still strong, although vaccination fear has grown significantly in recent decades. In some countries, this health anxiety has led to a rise in high refusal rates of vaccination. This has been linked to a fear of high threads of death from vaccinepreventable diseases [10]. In this context, the influence of media, particularly social media, appears to play a major role in the emergence of fear from the side effects of COVID-19 vaccines. Several studies have shown that fears remain a continuum of individual behavior and responses to every pandemic circumstance [5]. COVID-19 vaccines are now available in several countries, indeed, for Kurdistani people in Iraq. Early in March, the Health Ministry of the Kurdistan Region started an online registration system for the COVID-19 vaccine (https:// vac.health.digital.gov.krd/?lang=en). Officially, vaccines manufacture by Pfizer, AstraZeneca, and Sinopharm are available in our locality. The general health workers and frontline health professionals as well as the elderly people will be given priority in the vaccination program. Therefore, in this exceptional circumstance, it is noteworthy that this is the first study aimed to determine the fear of the COVID-19 vaccination and the role of factors associated with fear in the Iraqi Kurdistan region.

\section{Methods}

\section{Study design}

In the Kurdistan Regional Government (KRG) of Iraq, a quantitative method was used to perform a descriptive cross-sectional online survey among Kurdish residents in four governorates (Erbil, Slemani, Duhok, and Halabja). All participants have been asked to agree to non-obligatory participation conditions via a wellformulated questionnaire preceded by consent on the Web-based Google platform. Participants had the option to withdraw from the study at any time. The planned research period was from April 6, 2021, to April 20, 2021. The questionnaire form was created by the researchers and uploaded via Google form and distributed online through platforms, namely, Emails, What's up, Viber, and Facebook, over 2 weeks. A convenience sampling technique was applied to collect data from $n=1237$ participants. However, only $n=1188$ participants were included from the general population in our survey, and 49 responders were excluded due to incomplete replies to all questionnaire items. Ethical approval was obtained from the Scientific Committee at the College of Nursing, University of Duhok.

\section{Scales and assessments}

The fundamental reasons behind this element of health anxiety disorder were to measure the degree of fear of vaccination against COVID-19 and to analyze the primary sources of information on the COVID-19 vaccines in the surveyed sample. For the identification of fear towards COVID-19 vaccination, we used multiple-choice format fear scales which were conceptualized and formulated by the researchers by a simple modification. Hence, based on an available review, 10-point Likerttype scales were chosen to assess the level of fear of vaccination. They had been successfully used in multiple cross-sectional studies analyzing vaccine fear, vaccine acceptance, and perceived risk of vaccination [2, 11-14]. On this scale, individuals are asked to provide a score between 0 and 10 for their level of fear of being vaccinated against SARS-Cov2, ranging from "0-no fear" to "10-very high level of fear." After completion of data collection, the studied population was divided into three scores of fear which range from 0 to 3 "least fear", 4 to 6 "medium fear", and 7 to 10 "highest fear" (2). The questionnaire consists of sixteen short answer questions divided into three parts including independent variables such as age, gender, residential area, educational level, and occupation. In addition to the demographic data, some questions were asked to explore factors and reasons related to fear towards COVID-19 vaccination, as a second and a third part of the questionnaire were asked.

\section{Data analysis}

The crossing between the three levels of fear intensity to identify variables associated with fear was calculated using a table of frequencies and percentages. The chisquare test was used to measure statistical significance for the entire work. Graphs were used to create the figures, and all $p$ values (statistical significance $p<0.05$ ) were determined. Version 23 of IBM SPSS Statistics was used (IBM Corporation, Armonk, New York, USA).

\section{Results}

Table 1 shows that a total of 1188 participants were classified into three categories based on their fear of receiving the COVID-19 vaccine. Among them, 408 (34.3\%) had a low level of fear, 674 (56.7\%) had a medium level of fear, and $106(8.9 \%)$ had a high level of fear. This implies that the majority of the participants were moderately afraid. When the tertiles were compared by variables (Table 1 ), we found that there were statistically significant variations by sex $(p<0.001)$. Women have a higher level of fear than men by $32.66 \%$ of medium level and $4.97 \%$ of high level. Participants aged 18-24, 25-34, and 35-44 were the most fearful than other ages $(p<$ 0.002). Regarding the type of occupation, compared to other occupation categories, the majority of study participants were government employees (30.31\%) and students (27.87\%), and they had a highly significant association $(p<0.001)$ with dread. In terms of education, those with a diploma/bachelor's degree had a higher level of fear, with a significant association $(p<0.002)$. 
Table 1 Levels of fear according to socio-demographic characteristics during the COVID-19 vaccination

\begin{tabular}{|c|c|c|c|c|c|}
\hline Variables & Low, $N(\%)$ & Medium, $N(\%)$ & High, $N(\%)$ & Total & $p$ value \\
\hline General population & $408(34.3 \%)$ & $674(56.7 \%)$ & $106(8.9 \%)$ & 1188 & \\
\hline \multicolumn{6}{|l|}{ Sex } \\
\hline Male & $228(19.19)$ & $286(24.07)$ & 47 (3.96) & 561 & \multirow[t]{2}{*}{$<0.001^{* *}$} \\
\hline Female & $180(15.15)$ & $388(32.66)$ & $59(4.97)$ & 627 & \\
\hline \multicolumn{6}{|l|}{ Age } \\
\hline $18-24$ & $120(10.10)$ & $243(20.46)$ & 47 (3.96) & 410 & \multirow[t]{6}{*}{$<0.002^{*}$} \\
\hline $25-34$ & $126(10.60)$ & $238(20.03)$ & $29(2.44)$ & 393 & \\
\hline $35-44$ & $116(9.77)$ & $128(10.79)$ & $17(1.43)$ & 261 & \\
\hline $45-54$ & $33(2.78)$ & 38 (3.19) & $5(0.42)$ & 76 & \\
\hline $55-64$ & $11(0.92)$ & $25(2.10)$ & $7(0.59)$ & 43 & \\
\hline $65+$ & $2(0.17)$ & $2(0.17)$ & $1(0.08)$ & 5 & \\
\hline \multicolumn{6}{|l|}{ Education } \\
\hline Lower than high school & 24 & 33 & 10 & 67 & \multirow[t]{4}{*}{$<0.002^{*}$} \\
\hline High school & 33 & 35 & 11 & 79 & \\
\hline Diploma/bachelor & 263 & 485 & 77 & 825 & \\
\hline H.diploma/Master/Ph.D & 88 & 121 & 88 & 217 & \\
\hline \multicolumn{6}{|l|}{ Occupation } \\
\hline Healthcare workers & 117 (9.59) & $148(11.27)$ & $14(0.92)$ & 279 & \multirow[t]{6}{*}{$<0.001^{* *}$} \\
\hline Government employee & $128(10.77)$ & $203(17.08)$ & $27(2.27)$ & 358 & \\
\hline Self-employee & $22(1.85)$ & $23(1.93)$ & $5(0.42)$ & 50 & \\
\hline Private sector & $17(1.68)$ & $26(3.36)$ & $3(0.42)$ & 46 & \\
\hline Students & $86(10.21)$ & $205(17.25)$ & $40(3.36)$ & 331 & \\
\hline Jobless & $38(3.19)$ & $68(5.72)$ & $18(1.51)$ & 124 & \\
\hline \multicolumn{6}{|l|}{ Province } \\
\hline Hawler & $183(15.40)$ & $259(21.80)$ & 38 (3.19) & 480 & \multirow[t]{4}{*}{$0.003^{*}$} \\
\hline Sulaymaniyah & $50(4.20)$ & $103(8.67)$ & $6(0.50)$ & 159 & \\
\hline Duhok & $168(14.14)$ & $288(24.24)$ & $61(5.13)$ & 517 & \\
\hline Halabja & $7(0.58)$ & $24(2.02)$ & $1(0.08)$ & 32 & \\
\hline
\end{tabular}

$x^{2}$ chi-square test; ${ }^{*} p<0.05$ is significant; ${ }^{* *} p<0.001$ is highly significant

The results demonstrated a statistically significant difference between provinces $(p<0.003)$ : a high proportion of samples were from Duhok province 517 (43.51\%), followed by Hawler 480 (17.08\%).

Table 2 indicates that the majority of the participants (60.35\%) were not infected with COVID-19. Approximately $78 \%$ and $85 \%$ of the sample did not have a previous seasonal influenza vaccine or chronic diseases, respectively. Even though the majority of study participants $(63.46 \%)$ did not lose a family member as a result of the COVID-19 pandemic, we discovered a statistically significant connection between fear and losing a family member. Meanwhile, more than half of the participants (51.85\%) declared that the primary sources of information were social media/Internet, and we found a strong connection between sources of information and levels of fear $(p>0.001)$.
When comparing participants who were vaccinated with COVID-19 to those who were not, the vast majority of study respondents, including medical professionals (91.4\%) and non-healthcare workers (90.65\%), were not vaccinated during the period of this survey. However, healthcare workers were more willing and got vaccinated; a positive relation $(p>0.001)$ is identified in Fig. 1.

Concerning the association between fear and the type of COVID-19 vaccine, Fig. 2 shows that there is a significant relationship between types of vaccine and fear $(p>0.001)$. The AstraZeneca and Pfizer vaccines frightened the most people $(39.9 \%$ and $34.01 \%$, respectively).

In comparison to the other factors, $45.03 \%$ of samples reported fear of COVID-19 vaccines due to side effects, particularly blood clotting $(p>0.016)$ (Fig. 3 . 
Table 2 Relevant responses to the COVID-19 vaccine

\begin{tabular}{|c|c|c|c|}
\hline Variable & Number $(N)$ & Percent (\%) & $p$ value \\
\hline \multicolumn{4}{|c|}{ Q6/ Have you been infected and diagnosed with COVID-19? } \\
\hline Yes & 471 & 39.64 & \multirow[t]{2}{*}{0.204} \\
\hline No & 717 & 60.35 & \\
\hline \multicolumn{4}{|c|}{ Q7/ Have you lost any family members due to COVID-19? } \\
\hline Yes & 434 & 36.53 & \multirow[t]{2}{*}{$0.001^{* *}$} \\
\hline No & 754 & 63.46 & \\
\hline \multicolumn{4}{|l|}{ Q8/ Do you suffer from a chronic medical condition? } \\
\hline Yes & 167 & 14.05 & \multirow[t]{2}{*}{0.449} \\
\hline No & 1020 & 85.85 & \\
\hline \multicolumn{4}{|c|}{ Q9/ Did you receive any previous seasonal influenza vaccine? } \\
\hline Yes & 263 & 22.13 & \multirow[t]{2}{*}{0.216} \\
\hline No & 925 & 77.87 & \\
\hline \multicolumn{4}{|l|}{ Sources } \\
\hline Social media/Internet & 616 & 51.85 & \multirow[t]{7}{*}{$0.001^{* *}$} \\
\hline International organizations such as WHO/CDC & 192 & 16.16 & \\
\hline Television & 127 & 10.69 & \\
\hline Healthcare professionals & 109 & 9.17 & \\
\hline Family/friends & 67 & 5.63 & \\
\hline Government agencies & 78 & 6.50 & \\
\hline Total & 1188 & 100.00 & \\
\hline
\end{tabular}

$X^{2}$ chi-square test; ${ }^{*} p<0.05$ is significant; ${ }^{* *} p<0.001$ is highly significant

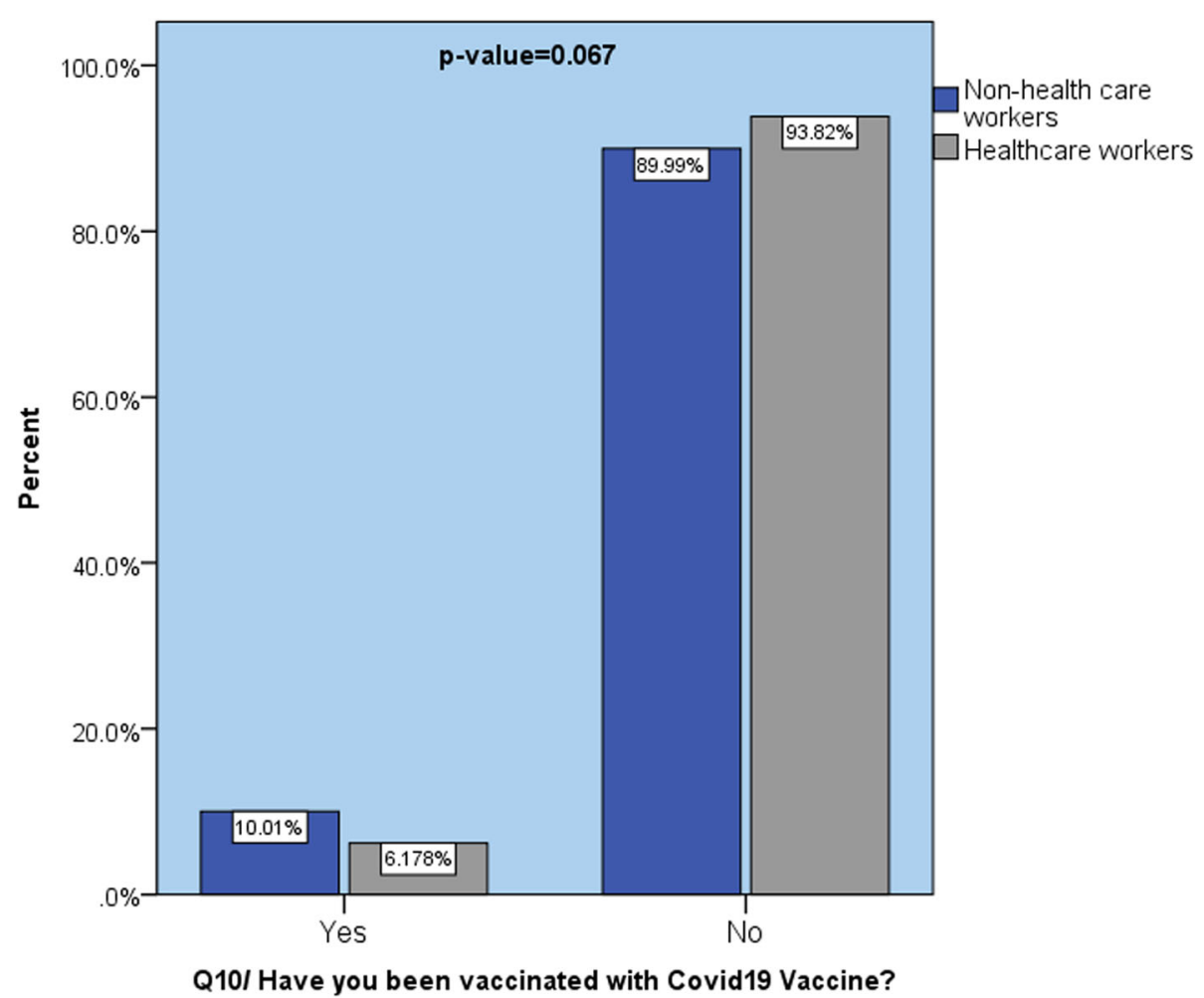

Fig. 1 Comparison of COVID-19 vaccination among healthcare and non-healthcare workers 


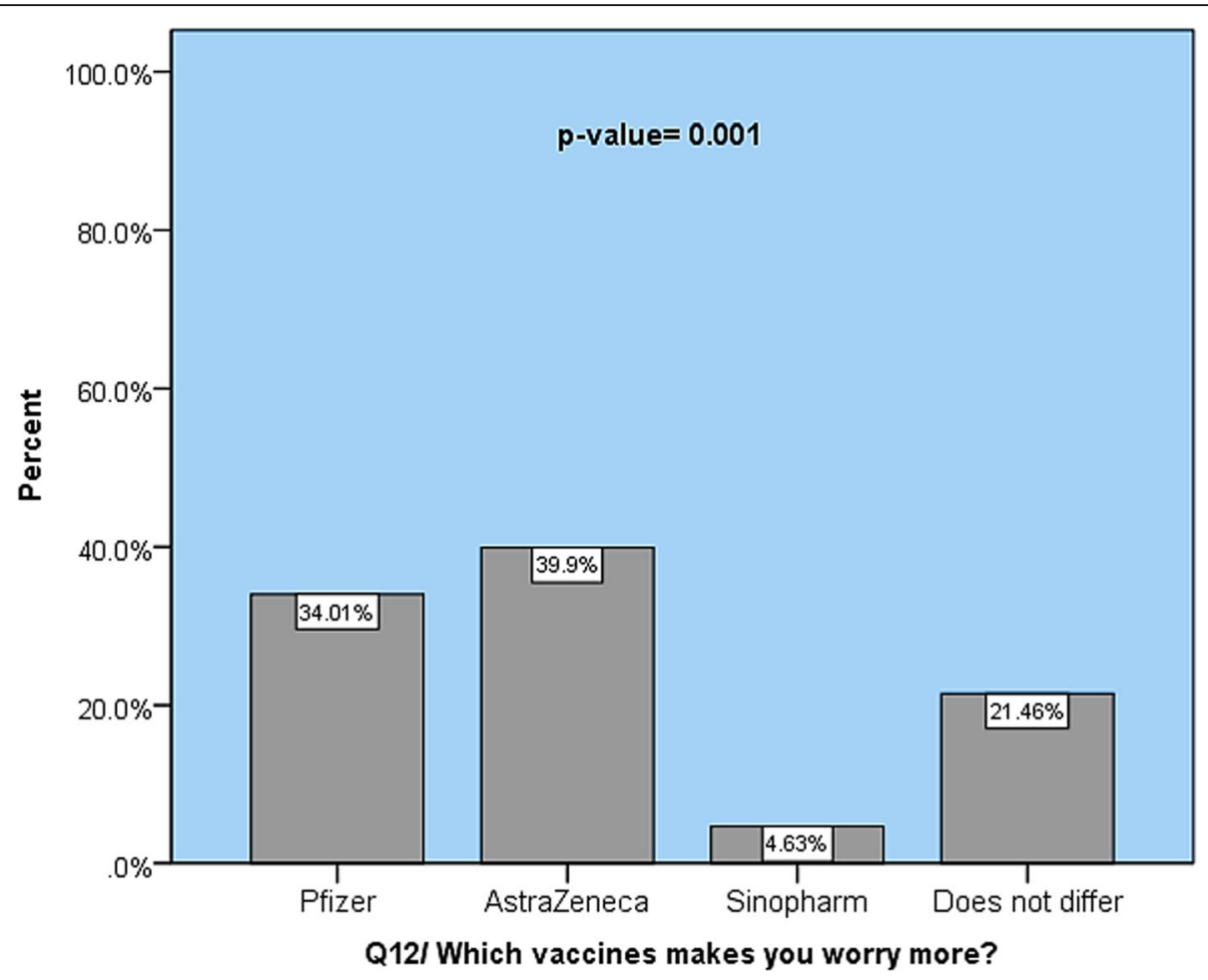

Fig. 2 Public response to types of COVID-19 vaccines concerning fear

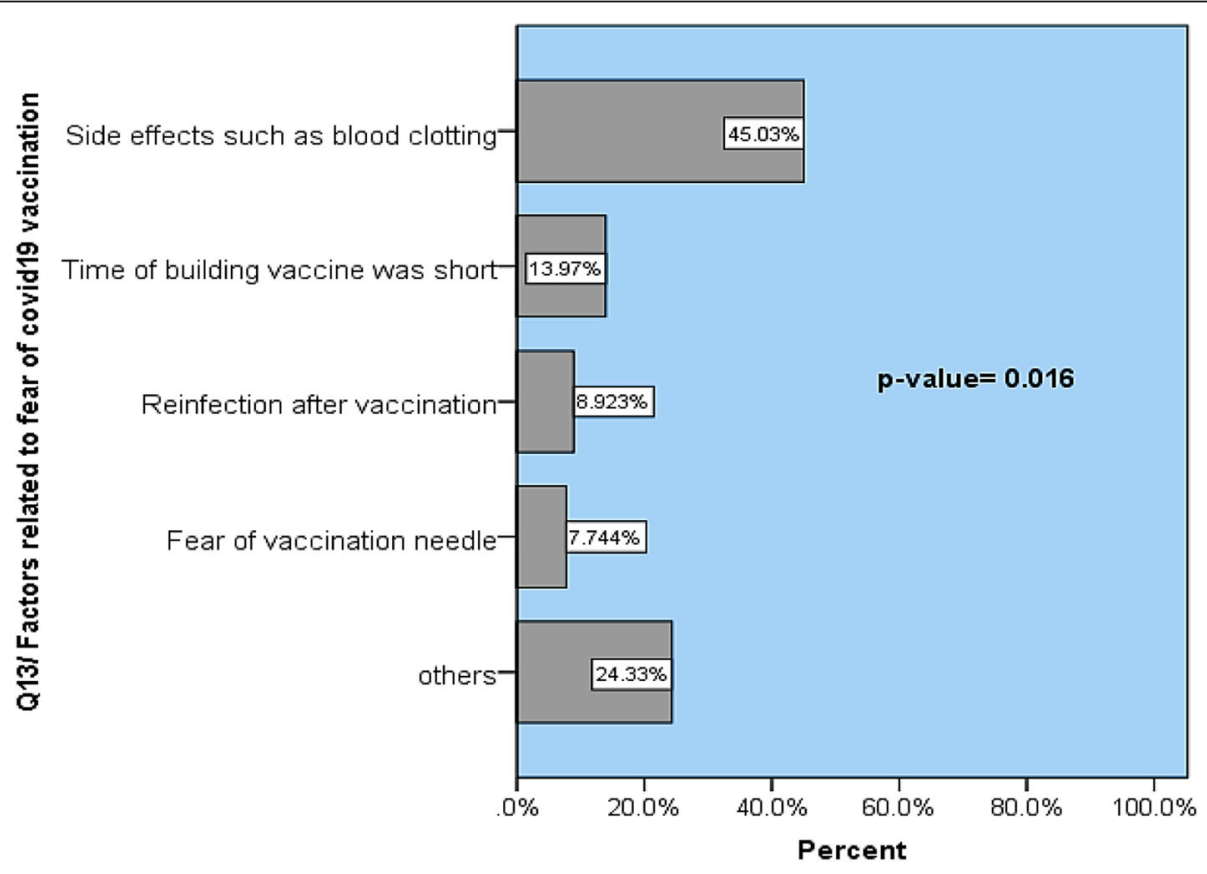

Fig. 3 Reasons affecting fear of COVID-19 vaccination 


\section{Discussion}

On March 11, 2020, the World Health Organization declared the outbreak of COVID-19 as a pandemic disease [15]. Fear, anxiety, and hesitancy are all present in the current COVID-19 pandemic, which is thought to be an ideal environment for the spread of uncertainty among the population [16-19]. Vaccines have emerged as savior methods in the face of the world's greatest health and economic crisis recently [20]. The present study aimed to determine fear of COVID-19 vaccination and their association with related factors. The results illustrate that women; people aged 18-24, 25-34, and 55-64; government employees; and students all had a high level of fear of the COVID-19 vaccine. Male and healthcare workers, on the other hand, were less afraid. Women experience more health anxiety than males as a result of a public health issue and they experience more fear, and this can be observed due to gender differences [21, 22]. Furthermore, women were the most affected in a study conducted in Peru among 3887 persons on the fear perception of the COVID-19 vaccination [2], as it was in Iraq [23], which is consistent with the ongoing study. Another notable finding in this study is that young people and mature adults were more fearful of the COVID-19 vaccines, which is consistent with other studies conducted during the COVID-19 pandemic in the Kurdistan area [24], Iraq [23], Austria [25], and the UK [26]. These age groups are using technology more than the elderly. This indicates that the younger generation is more vulnerable to depression, anxiety, and fear.

In our work, different factors were significantly ( $p$ value $=0.016$ ) associated with fear of COVID-19 vaccination and the main reasons were fear of side effects such as coagulopathy and time of building the vaccines, while fear of needle was the least factor. This is in line with accumulated evidence that the major reason for hesitation or refusal of COVID-19 vaccines was fear of side effects [20, 27-29]. Many articles have been published in the scientific literature on the contents and side effects of vaccines $[27,30]$.

Importantly, we revealed that there was a strong relationship ( $p$ value $=0.001)$ between losing a family member and fear of COVID-19 vaccines, while previous COVID-19 infection, chronic illness, and obtaining seasonal influenza vaccine were not. Many studies during the COVID-19 pandemic observed a connection between fear of transmitting the disease and losing family members [31-33]. However, recent researches show the association between vaccine acceptance and other related variables such as previous influenza vaccination and having a history of chronic diseases, respectively $[28,34]$.

Social media is one of the main channels for updating COVID-19 information $[35,36]$. Participants are frequently exposed to social media. Recent studies in the Kurdistan region have already shown the effect of social media on mental health during COVID-19 [24], and this study also discovered a major connection $(p<0.001)$ between fear of vaccine use and social media. To address this phenomenon, policymakers, regulators, the Ministry of Health, education, and media professionals should cooperate, and only data that has been thoroughly reviewed should be made accessible to the general population. Furthermore, fear was strongly $(p=0.001)$ associated with types of available vaccines, with the vast majority have fear of AstraZeneca, Pfizer, and Moderna, respectively. In a study of $n=1020$ participants conducted in Poland, Pfizer and Moderna received a high level of trust, while Oxford/AstraZeneca received a low level of trust [14]. There are some possible explanations for the AstraZeneca vaccine's apprehension. Firstly, knowledge regarding AstraZeneca's side effects was more widely disseminated than other forms [37, 38]; second, the media and expert groups paid more attention to the mechanism of action of mRNA vaccines, resulting in a higher degree of understanding and acceptance [14]. We also observed that only about $9.2 \%$ of participants were vaccinated at the time of the survey, with healthcare professionals being the most enthusiastic about the vaccine program and engaging in it $[29,39,40]$. High intention to obtain COVID-19 vaccines if they were available has been reported by [1, 41, 42], which disagrees with the results of the ongoing research.

\section{Limitations}

This research has some limitations that should be highlighted. To begin with, since our study is a crosssectional one, we can only show you a snapshot of vaccine anxiety at one point in time. Second, due to the restrictions and measurements taken during the COVID-19 pandemic, this is an online questionnaire survey that may affect the generalizability of the sample. Thus, since it is an Internet-based survey, the majority of respondents were young adults, and the elderly had fewer opportunities to participate. Third, since this study was conducted at the beginning of the COVID-19 vaccination campaign when people were fearful of its use because it was new, they may respond differently when the vaccination campaign became part of the policymakers, Ministry of Health, and educational strategies. Furthermore, there was a chance of selection bias due to online participation in which a certain group of people can participate rather than different categories in the community. The study was also prone to external validity as the population we chose is those who use the Internet while those who do not use the Internet did not have a chance to be included in the current study. 


\section{Conclusions}

In the present study, we conclude that fear of COVID19 vaccines is widespread among Kurdish people. Female sex, younger ages, losing family members, social media use, vaccine side effects, and types of vaccine are strongly associated with fear, while male sex, healthcare workers, and other variables are not associated with fear. According to our results, more psychological and physical preparedness is required to deal with health emergencies, and authorities and the Ministry of Health should address and develop these mental issues.

\section{Abbreviations}

COVID-19: Coronavirus disease 2019; SARS: Severe acute respiratory syndrome coronavirus 2; mRNA: Messenger ribonucleic acid; KRG: Kurdistan Regional Government

\section{Acknowledgements}

We would like to express our gratitude to all respondents who decided to take part in this online survey; their participation is greatly valued.

\section{Authors' contributions}

We declare that the following authors contributed to this work as follows: Al wrote the "Discussion" and "Data analysis" sections and review. D.SH and AA wrote the "Background" section and constructed the questionnaire. AK wrote the "Methods" section. RY wrote the "Results" section. SH.F participated in the data collection and entry. SK participated in editing, reviewing, and revising the final manuscript. All authors agreed and approved the final manuscript to be published in this journal.

\section{Funding}

There were no funding sources to support this study.

\section{Availability of data and materials}

The datasets that were generated during and/or analyzed during the current study are available from the corresponding author on reasonable request.

\section{Declarations}

\section{Ethics approval and consent to participate}

The Scientific Committee of the University of Duhok, College of Medicine, granted ethical permission for the study before it began collecting data (no reference number available). At the start, each participant in this online survey provided written informed consent. All rights to the privacy and secrecy of all participants were respected.

\section{Consent for publication}

N/A

\section{Competing interests}

The authors declare that they have no competing interests.

\footnotetext{
Author details

${ }^{1}$ Bardarash Technical Institute, Nursing Department, Duhok Polytechnic University, Duhok Governorate, Duhok, Kurdistan Region, Iraq. ${ }^{2}$ College of Nursing, Nursing Department, Duhok University, Duhok Governorate, Duhok, Kurdistan Region, Iraq. ${ }^{3}$ Cardiac Center, Erbil Governorate, Erbil, Kurdistan Region, Iraq. ${ }^{4}$ Azadi Teaching Hospital, Duhok, Kurdistan Region, Iraq. ${ }^{5}$ Directorate of Health-Slemani Administration, Ministry of Health, Sulaymaniyah Governorate, Sulaymaniyah, Kurdistan Region, Iraq. ${ }^{6}$ Surgical Specialist Hospital-Cardiac Center Sulaymaniyah, Ministry of Health, Erbil Governorate, Erbil, Kurdistan Region, Iraq.
}

Received: 31 May 2021 Accepted: 9 July 2021

Published online: 27 July 2021

\section{References}

1. Sherman SM, Smith LE, Sim J, Amlôt R, Cutts M, Dasch H, Rubin GJ, Sevdalis N (2020) COVID-19 vaccination intention in the UK: results from the COVID19 vaccination acceptability study (CoVAccS), a nationally representative cross-sectional survey. Hum Vaccine Immunother 25(6):1-1621. https://doi. org/10.1080/21645515.2020.1846397

2. Mejia CR, Rodriguez-Alarcon JF, Vera-Gonzales JJ, Ponce-Lopez VL, Chamorro-Espinoza SE, Quispe-Sancho A, Marticorena-Flores RK, VarelaVillanueva ES, Pedersini P, Tovani-Palone MR (2021) Fear perception of the COVID-19 pandemic in Peru. Electron J Gen Med 18(3):em285. https://doi. org/10.29333/ejgm/9764

3. Yang Y, Peng F, Wang R, Guan K, Jiang T, Xu G, Sun J, Chang C (2020) The deadly coronaviruses: the 2003 SARS pandemic and the 2020 novel coronavirus epidemic in China. J Autoimmunity 109:102434. https://doi. org/10.1016/j.jaut.2020.102434

4. Lurie N, Saville M, Hatchett R, Halton J (2020 May 21) Developing Covid-19 vaccines at pandemic speed. New England Journal of Medicine. 382(21): 1969-1973. https://doi.org/10.1056/NEJMp2005630

5. Bendau A, Plag J, Petzold MB, Ströhle A (2021) COVID-19 vaccine hesitancy and related fears and anxiety. Int Immunopharmacol 27:107724. https://doi. org/10.1016/j.intimp.2021.107724

6. Dzinamarira T, Nachipo B, Phiri B, Musuka G (2021) COVID-19 vaccine rollout in South Africa and Zimbabwe: urgent need to address community preparedness, fears and hesitancy. Vaccines 9(3):250. https://doi.org/10.3390/ vaccines 9030250

7. Gupta T, Gupta SK (2020) Potential adjuvants for the development of a SARS-CoV-2 vaccine based on experimental results from similar coronaviruses. Int Immunopharmacol 18:106717. https://doi.org/10.1016/j. intimp.2020.106717

8. Janz NK, Becker MH (1984) The health belief model: a decade later. Health Educ Q 11(1):1-47. https://doi.org/10.1177/109019818401100101

9. Boddice R (2016 Feb) Vaccination, fear and historical relevance. History compass. 14(2):71-78. https://doi.org/10.1111/hic3.12297

10. Ropeik D (2013 Aug 8) How society should respond to the risk of vaccine rejection. Human vaccines \& immunotherapeutics. 9(8):1815-1818. https:// doi.org/10.4161/hv.25250

11. Albano L, Matuozzo A, Marinelli P, di Giuseppe G (2014) Knowledge, attitudes and behaviour of hospital health-care workers regarding influenza A/H1N1: a cross sectional survey. BMC Infect Dis 14(1):208. https://doi.org/1 $0.1186 / 1471-2334-14-208$

12. Alholm Z, Ault K, Zwick R, Fitzgerald S, Satterwhite C. Pregnant women's acceptance of hypothetical Zika vaccine. In Open Forum Infectious Diseases 2017 (4, Suppl 1, S458). Oxford University Press. https://dx.doi.org/10. 1093\%2Fofid\%2Fofx163.1167.

13. Yegit M, Ozkaya-Parlakay A, Emrah S (2021) Evaluation of COVID-19 vaccine refusal in parents. Pediatr Infect Dis J 40(4):e134-e136. https://doi.org/10.1 097/INF.0000000000003042

14. Rzymski P, Zeyland J, Poniedziałek B, Małecka I, Wysocki J (2021 Apr) The perception and attitudes toward COVID-19 vaccines: a cross-sectional study in Poland. Vaccines. 9(4):382. https://doi.org/10.3390/vaccines9040382

15. World Health Organization, 2020. Responding to community spread of COVID-19: interim guidance, 7 March 2020 (No. WHO/COVID-19/ Community_Transmission/2020.1). World Health Organization. Available at https://apps.who.int/iris/bitstream/handle/10665/331490/WHO-2019nCoVMentalHealth-2020.1-eng.pdf.

16. Romer D, Jamieson KH (2020) Conspiracy theories as barriers to controlling the spread of COVID-19 in the US. Soc Sci Med 263:113356. https://doi.org/1 0.1016/j.socscimed.2020.113356

17. Xiong J, Lipsitz O, Nasri F, Lui LM, Gill H, Phan L, Chen-Li D, lacobucci M, Ho R, Majeed A, McIntyre RS (2020) Impact of COVID-19 pandemic on mental health in the general population: a systematic review. J Affect Disorder 277: 55-64. https://doi.org/10.1016/j.jad.2020.08.001

18. Ball P, Maxmen A (2020) The epic battle against coronavirus misinformation and conspiracy theories. Nature 581(7809):371-374. https://doi.org/10.1038/ d41586-020-01452-z

19. Sallam M, Dababseh D, Yaseen A, Al-Haidar A, Ababneh NA, Bakri FG, Mahafzah A (2020) Conspiracy beliefs are associated with lower knowledge and higher anxiety levels regarding COVID-19 among students at the 
University of Jordan. Int J Environ Res Public Health 17(14):4915. https://doi. org/10.3390/ijerph17144915

20. Lin C, Tu P, Beitsch LM (2021 Jan) Confidence and receptivity for COVID-19 vaccines: a rapid systematic review. Vaccines. 9(1):16. https://doi.org/10.33 90/vaccines 9010016

21. Wang C, Pan R, Wan X, Tan Y, Xu L, Ho CS, Ho RC (2020 Jan) Immediate psychological responses and associated factors during the initial stage of the 2019 coronavirus disease (COVID-19) epidemic among the general population in China. International journal of environmental research and public health. 17(5):1729. https://doi.org/10.3390/ijerph17051729

22. Liu N, Zhang F, Wei C, Jia Y, Shang Z, Sun L, Wu L, Sun Z, Zhou Y, Wang Y, Liu W (2020 May 1) Prevalence and predictors of PTSS during COVID-19 outbreak in China hardest-hit areas: gender differences matter. Psychiatry research. 287:112921. https://doi.org/10.1016/j.psychres.2020.112921

23. Karim SK, Taha PH, Amin NMM, Ahmed HS, Yousif MK, Hallumy AM (2020) COVID-19-related anxiety disorder in Iraq during the pandemic: an online cross-sectional study. Middle East Curr Psychiatry 27(1):55. https://doi.org/1 0.1186/s43045-020-00067-4

24. Ahmad AR, Murad HR (2020) The impact of social media on panic during the COVID-19 pandemic in Iraqi Kurdistan: online questionnaire study. Journal of medical Internet research. 22(5):e19556. https://doi. org/10.2196/19556

25. Pieh C, Budimir S, Probst T (2020) The effect of age, gender, income, work, and physical activity on mental health during coronavirus disease (COVID19) lockdown in Austria. Journal of psychosomatic research, 136, p.110186. mental health during coronavirus disease (COVID-19) lockdown in Austria. J Psychosomatic Res 136:110186

26. Kwong AS, Pearson RM, Adams MJ, Northstone K, Tilling K, Smith D, FawnsRitchie C, Bould H, Warne N, Zammit S, Gunnell D. Mental health during the COVID-19 pandemic in two longitudinal UK population cohorts. medRxiv. 2020. doi: $10.1101 / 2020.06 .16 .20133116$.

27. Shaw CA, Tomljenovic $L$ (2013) Aluminum in the central nervous system (CNS): toxicity in humans and animals, vaccine adjuvants, and autoimmunity. Immunol Res 56(2):304-316. https://doi.org/10.1007/s12026013-8403-1

28. Akarsu B, Canbay Özdemir D, Ayhan Baser D, Aksoy H, Fidancı I, Cankurtaran M (2021) While studies on COVID-19 vaccine is ongoing, the public's thoughts and attitudes to the future COVID-19 vaccine. Int J Clin Pract 75(4): e13891. https://doi.org/10.1111/ijcp.13891

29. Papagiannis D, Rachiotis G, Malli F, Papathanasiou IV, Kotsiou O, Fradelos EC, Giannakopoulos K, Gourgoulianis KI (2021 Mar) Acceptability of COVID-19 vaccination among Greek health professionals. Vaccines. 9(3):200. https:// doi.org/10.3390/vaccines 9030200

30. Ball LK, Ball R, Pratt RD (2001) An assessment of thimerosal use in childhood vaccines. Pediatrics. 107(5):1147-1154. https://doi.org/10.1542/peds.107.5.1147

31. Zhang $Y$, Xie S, Wang P, Wang G, Zhang L, Cao X, Wu W, Bian Y, Huang F, Luo N, Luo M. Factors influencing mental health of medical workers during the COVID-19 outbreak. Front Public Health 2020;8. DOI: 10.3389/fpubh. 2020.00491.

32. De Brier N, Stroobants S, Vandekerckhove P, De Buck E (2020) Factors affecting mental health of health care workers during coronavirus disease outbreaks: a rapid systematic review. PloS one 15(12):e0244052. https://doi. org/10.1371/journal.pone.0244052

33. Kisely S, Warren N, McMahon L, Dalais C, Henry I, Siskind D. Occurrence, prevention, and management of the psychological effects of emerging virus outbreaks on healthcare workers: rapid review and meta-analysis. Bmj. 2020; 369. doi: 10.1136/bmj.m1642.

34. Gagneux-Brunon A, Detoc M, Bruel S, Tardy B, Rozaire O, Frappe P, BotelhoNevers $E$ (2021) Intention to get vaccinations against COVID-19 in French healthcare workers during the first pandemic wave: a cross-sectional survey. J Hosp Infect 108:168-173. https://doi.org/10.1016/j.jhin.2020.11.020

35. Gao J, Zheng P, Jia Y, Chen H, Mao Y, Chen S, Wang Y, Fu H, Dai J (2020 Apr 16) Mental health problems and social media exposure during COVID-19 outbreak. Plos one. 15(4):e0231924. https://doi.org/10.1371/journal.pone.0231924

36. Bao Y, Sun Y, Meng S, Shi J, Lu L (2020) 2019-nCoV epidemic: address mental health care to empower society. Lancet 395(10224):e37-e38. https:/ doi.org/10.1016/50140-6736(20)30309-3

37. Polack FP, Thomas SJ, Kitchin N, Absalon J, Gurtman A, Lockhart S, Perez JL, Pérez Marc G, Moreira ED, Zerbini C, Bailey R (2020) Safety and efficacy of the BNT162b2 mRNA Covid-19 vaccine. New Eng J Med 383(27):2603-2615. https://doi.org/10.1056/NEJMoa2034577
38. Voysey M, Clemens SA, Madhi SA, Weckx LY, Folegatti PM, Aley PK, Angus B, Baillie VL, Barnabas SL, Bhorat QE, Bibi S (2021) Safety and efficacy of the ChAdOx1 nCoV-19 vaccine (AZD1222) against SARS-CoV2: an interim analysis of four randomised controlled trials in Brazil, South Africa, and the UK. Lancet 397(10269):99-111. https://doi.org/10.1 016/S0140-6736(20)32661-1

39. Dror AA, Eisenbach N, Taiber S, Morozov NG, Mizrachi M, Zigron A, Srouji S, Sela E (2020) Vaccine hesitancy: the next challenge in the fight against COVID-19. Eur J Epidemiol 35(8):775-779. https://doi.org/10.1007/s10654-02 0-00671-y

40. Detoc M, Bruel S, Frappe P, Tardy B, Botelho-Nevers E, Gagneux-Brunon A (2020 Oct 21) Intention to participate in a COVID-19 vaccine clinical trial and to get vaccinated against COVID-19 in France during the pandemic Vaccine. 38(45):7002-7006. https://doi.org/10.1016/j.vaccine.2020.09.041

41. Pastorino R, Villani L, Mariani M, Ricciardi W, Graffigna G, Boccia S (2021) Impact of COVID-19 pandemic on flu and COVID-19 vaccination intentions among university students. Vaccines 9(2):70. https://doi.org/10.3390/va ccines 9020070

42. Killgore WD, Cloonan SA, Taylor EC, Dailey NS (2021) The COVID-19 vaccine is here-now who is willing to get it? Vaccines 9(4):339. https://doi.org/1 0.3390/vaccines 9040339

\section{Publisher's Note}

Springer Nature remains neutral with regard to jurisdictional claims in published maps and institutional affiliations.

\section{Submit your manuscript to a SpringerOpen ${ }^{\circ}$ journal and benefit from:}

- Convenient online submission

- Rigorous peer review

- Open access: articles freely available online

High visibility within the field

- Retaining the copyright to your article

Submit your next manuscript at $\boldsymbol{\nabla}$ springeropen.com 